\title{
Occurrence of the sandy beach mysids Archaeomysis spp. (Mysidacea) infested by epibiontic peritrich ciliates (Protozoa)
}

\section{Yukio Hanamura and Keizo Nagasaki}

Abstract. - The occurrence of the sandy beach mysids Archaeomysis spp. (Mysidacea) with epibiontic peritrich ciliates (Protozoa) has been studied. Epibiontic peritrich infestations were found on four Archaeomysis species collected from the western North Pacific. This study provided the evidence of existence of a previously undescribed symbiontic association between mysids and epibiontic ciliates. Overall incidence of infestation for Archaeomysis sp., A. kokuboi, A. vulgaris, and A. japonica hosting peritrichs averaged $74.7,75.6$, 22.3 , and $1.2 \%$, respectively, with higher incidence in the northern populations for the genus. No mysids carrying peritrichs were found in specimens taken from central to southwestern Japan. Thus, the attached ciliates were considered to have a cold water affinity. Seasonal observations over one year suggested that the mysid-ciliate association in the northern waters of Japan was a year-round phenomenon. The incidence of infested mysids in the harsh zone of sandy beaches was noticeably higher than that in the infralittoral bottoms, suggesting that the habitat of host mysids may be a factor affecting the infestation success of the peritrichs.

\section{Introduction}

Mysids are a group of crustaceans often subject to infestations by a variety of parasites such as ellobiopsids, ciliates, cestodes, and crustaceans. According to previous records (Tattersall \& Tattersall,
1951; Hoenigman, 1960; Mauchline, 1980; Evans et al., 1981), however, only five species of nearly 1,000 nominated mysids have been reported to be associated with epibiontic ciliates belonging to the orders of Apostomatia, Suctorida, and Peritrichida; i.e., Siriella jaltensis and $S$. adriatica carrying Ophryodendron sp. and Paracineta sp., Mysis relicta carrying Acineta ulvroa and Tokophyra sp., Praunus neglecta carrying Epistylis sp., and $P$. flexuosus carrying Zoothamnium sp. and an unidentified apostome. Generally, most of this literature is yet in a descriptive stage, reporting merely on the presence of ciliates on mysids. Among them, the study by Evans et al. (1981), who reported on the association of the suctorian Tokophyra sp. on Mysis relicta in the Great Lakes region, is a notable exception because the analysis extended to the size relations between ciliates and host mysids. Consequently, our knowledge on epibiontic ciliates of mysids is currently very limited.

Over the course of systematic and biogeographical studies of shallow-water mysids in the North Pacific, many specimens of the gastrosaccine mysid genus Archaeomysis hosted with epizoic ciliates have frequently been found from sandy beach collections. This paper provides new information on the incidence of symbiontic association of peritrich ciliates with the mysid genus Archaeomysis, and discusses seasonal, geographical and bathymetric variations of the incidence of this association. 
Materials and Methods

An extensive collection of mysids belonging to the genus Archaeomysis was made from the intertidal zone of sandy beaches and infralittoral bottoms of various geographic localities around the Japan and its neighboring waters (Fig. 1) for the study of taxonomy and biogeographical distribution of this group of mysids by the senior author. From part of these collections, all preserved in $70 \%$ alcohol, Archaeomysis species including Archaeomysis sp., A. kokuboi, A. vulgaris, and $A$. japonica were selected and were used for the present investigation. As a total, more than 2,000 mysids were examined for attached ciliates (Table 1).

Observations were made under a light microscope, then an electron scanning microscope (SEM) was used for a detailed observation, the latter was prepared following almost the procedure of Takayama

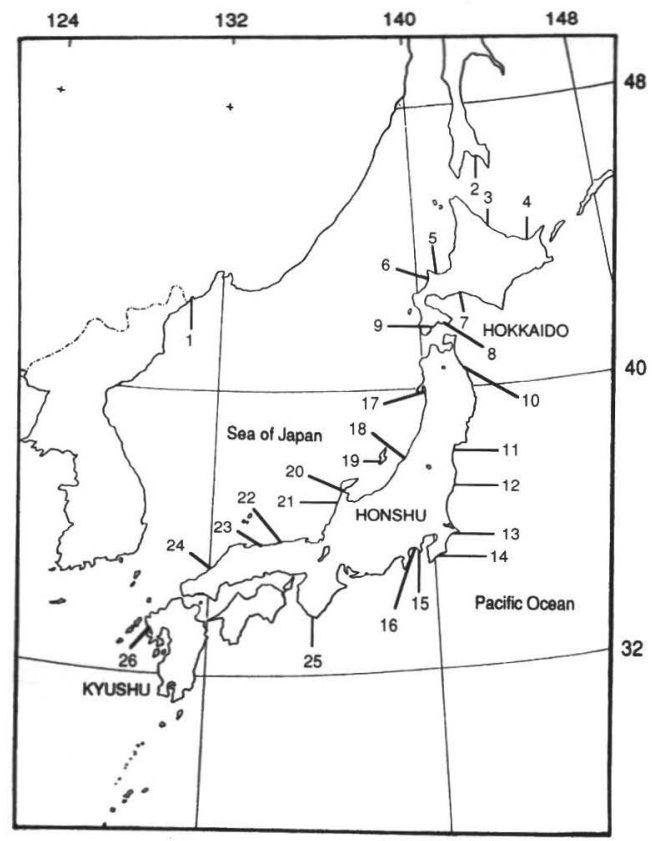

Fig. 1. Map showing sampling locations of Archaeomysis spp. on the coasts of western North Pacific. Numerals indicate sampling sites, and sampling details, see also Table 1.
(1981). In this study, the abundance of ciliates attached to mysids was not quantified. Sex and size of mysids were not determined, since a preliminary examination showed no clear trend for the incidence level between males and females, or between body size classes.

The identification of the host mysids was made based on the results of recent studies by Jo \& Hanamura (1993), and Hanamura et al. (1996). The identification of epibiontic ciliates was made by $\mathrm{Dr}$. A. Warren of the Natural History Museum, London. Because of examinations of preserved specimens, the identification of ciliates could not be definite, so the ciliates were tentatively designated as "peritrichs" throughout this report.

\section{Results}

All the four species of the sandy beach mysids of the genus Archaeomysis were found to be infested by epizoic peritrichs, and the number of peritrichs per mysid varied from a single to more than some hundreds. From morphological details from observation with SEM, two types of ciliates, at least, could be identified; i.e., contractile peritrichs (possibly a member of Vorticellidae, Fig. 2a-d) and non-contractile colonial peritrichs (probably a member of Epistylidae, Fig. 3a-e).

All specimens of Archaeomysis carried the peritrichs primarily on the pleopods, including on their setae (Fig. 2a). The epibiontes were also located on the thoracic limbs, antennae, mouthparts, and uropods, especially at the articulation between the two segments of these appendages (Fig. 3d). For heavily infested mysids, the peritrichs were observed at the inside of the lateral surface of carapace, the ventral sternites, the lateral portions of the thoracic somites covered by the carapace, the inside of the first pleuron of females, the female marsupium, and even on the penis of males. However, no peritrichs were found on the 
Table 1. Summary of sampling records and incidence of infestation by epibiontic peritrichs in each sample. For the number of sampling sites, see Fig. 1. For the calculation of mean $(\overline{\mathbf{x}})$ and standard deviation (in parentheses) of infestation, original data were transformed to arcsin.

\begin{tabular}{|c|c|c|c|c|}
\hline $\begin{array}{l}\text { Sampling } \\
\text { site } \\
\text { (Ref. to Fig. 1) }\end{array}$ & $\begin{array}{l}\text { Sampling } \\
\text { details }\end{array}$ & $\underset{\text { size }}{\text { Sample }}$ & $\begin{array}{l}\text { Body } \\
\text { length } \\
(\mathrm{mm})\end{array}$ & $\begin{array}{c}\text { Infes } \\
\text {-tation } \\
(\%)\end{array}$ \\
\hline \multicolumn{5}{|c|}{ Archaeomysis sp. } \\
\hline $1 \quad \mathrm{i}$ & intertidal zone, 13 Sep 1982 & 5 & 6.5 -са 8 & 40 \\
\hline 2 & intertidal zone, date unknown & 6 & $9.5-$ ca 12.5 & 100 \\
\hline 3 & intertidal zone, 3 Jun 1991 & 50 & $9.8-12.5$ & 100 \\
\hline 4 & intertidal zone, 10 Aug 1991 & 62 & 4.6 -ca 9.5 & 91.9 \\
\hline $7 \quad \mathrm{i}$ & intertidal zone, 28 Mar 1990-22 Mar 1991 & 397 & $3.0-$ ca 15.0 & 79.8 \\
\hline \multicolumn{2}{|c|}{ (total inds) } & 515 & $\overline{\mathbf{x}}=7$ & $(17.19)$ \\
\hline
\end{tabular}

Archaeomysis kokuboi

$\begin{array}{ll}8 & \text { intertidal zone, } 1 \text { Jun } 1990 \\ 9 & \text { intertidal zone, 15 Aug } 1987 \\ 10 & \text { intertidal zone, 5 Nov } 1988 \\ 11 & \text { intertidad zone, 15 May } 1991 \\ 12 & \text { intertidal zone, 24 Sep } 1990 \\ 17 & \text { intertidal zone, 9 Jul 1990 } \\ 19 & \text { intertidal zone, 22 Apr } 1990 \\ \text { (total inds) }\end{array}$

\begin{tabular}{rcr}
51 & $7.2-13.4$ & 100 \\
30 & up to 10.7 & 73.3 \\
13 & $5.8-10.5$ & 46.2 \\
42 & $5.5-107$ & 71.4 \\
52 & $4.7-9.7$ & 36.5 \\
100 & $5.0-11.4$ & 94 \\
100 & $5.0-$ ca 14 & 96 \\
388 & \multicolumn{1}{c}{$=75.6(19.85)$}
\end{tabular}

\section{Archaeomysis vulgaris}

11 intertidal zone, 17 May 1991

12 intertidal zone, 24 Sep 1990

13 intertidal zone, 12 Jan 1991

14 intertidal zone, 19 Dec 1990

15 intertidal zone, 2-5 May 1991

16 intertidal zone, 5 Apr-4 May 1991

18 intertidal zone, $16 \mathrm{Jul} 1986$

20 intertidal zone, $10 \mathrm{Feb} 1991$

21 intertidal zone, $30 \mathrm{Apr} 1986$

$23 \quad 0.3-0.5 \mathrm{~m}, 4$ Apr 1991

24 intertidal zone, 9 Oct 1994

25 intertidal zone, 5 Jan 1992 \& 31 Dec 1993

(total inds)

$\begin{array}{cr}7.3-9.5 & 75 \\ 4.3-9.3 & 10.5 \\ 6.5-9.7 & 100 \\ \text { ca } 4.5-10.1 & 1.9 \\ 2.5-10.5 & 53.3 \\ 2.8-9.1 & 12.3 \\ 7.1-7.7 & 80 \\ 5.2-9.5 & 0 \\ 6.8-11.6 & 0 \\ 5.3-13.2 & 0 \\ 4.7-\operatorname{ca~} 7.5 & 0 \\ 4.6-8.1 & 0 \\ \overline{\mathrm{x}}=22.3(27.27)\end{array}$

Archaeomysis japonica

\begin{tabular}{clrrr}
5 & 3-20 m, 13 Apr 1989-21 Feb 1990 & 119 & $8.0-12.5$ & 6.7 \\
6 & 0-6 m, 19 Apr 1992 (plankton sample) & 29 & $9.5-13.0$ & 0 \\
7 & 11-17 m, 14 Jun 1984-7 Feb 1985 & 82 & $4.1-c a 15$ & 8.5 \\
18 & 3-15 m, 23 Jul 1986 \& 16 Apr 1991 & 125 & $5.0-9.4$ & 0 \\
22 & 3-5 m, 15 Mar 1974 \& 162 & $5.2-14.9$ & 0 \\
26 & 0.2-12 m, 28 Jun 1982-13 May 1983 & 120 & $2.5-11.0$ & 0 \\
(total inds) & 617 & $\overline{\mathrm{x}}=1.2(7.85)$ \\
\hline
\end{tabular}

dorsal surface of the body (including the eye-stalks, antennule, dorsal surfaces of antennal scale, uropods and telson). The locations of the body where the ciliate attached were common to all four species of Archaeomysis examined in this study.
The attachment disk appeared to be not penetrating into the cuticles of the hosts. No bacterial colonies were detected around the discs (Fig. 3e). The smallest mysid carrying ciliates was $2.5 \mathrm{~mm}$ in length, on which only a single trophont 


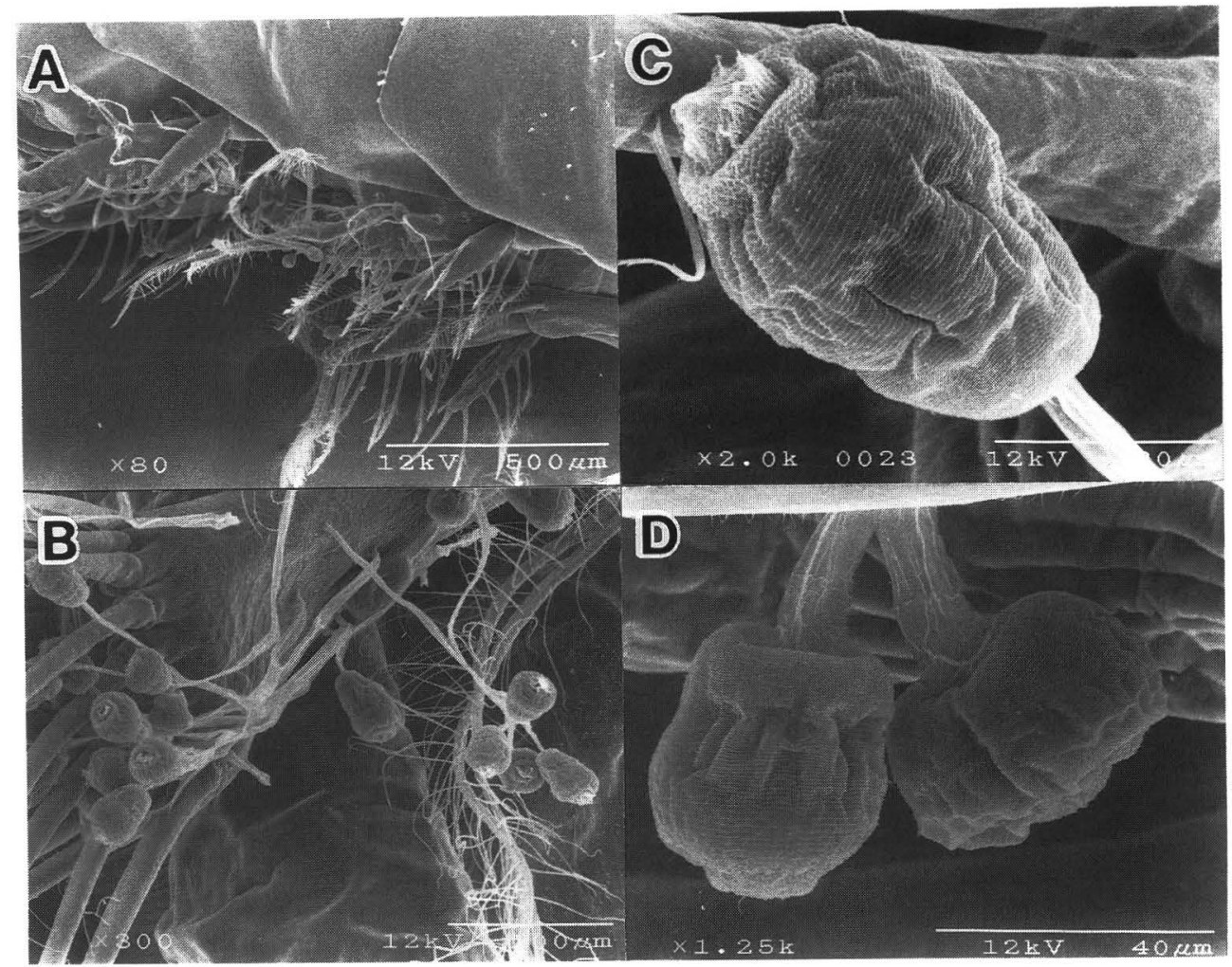

Fig. 2. Archaeomysis sp. infested with epibiontic peritrichs: a, abdomen of adult male infested with many peritrichs on the pleopods; $b$, enlarged figure showing non-contractile peritrich colonies attached to the distal part of pleopod; c zooid of non-contractile peritrich; $d$, same as the precedent.

was observed. Adult mysids occasionally were found to carry a larger number of ciliates.

Incidence of specimens carrying the peritrichs in each mysid species is summarized in Table 1. Overall incidence of infestation for Archaeomysis sp., A. kokuboi, $A$. vulgaris and $A$. japonica hosting the epibiontes averaged $74.7,75.6$, 22.3 and $1.2 \%$, respectively. Among these four mysid species, greater level of infestation was found in Archaeomysis sp. and A. kokuboi, occurring along the coasts of northern Honshu, Hokkaido and Pojet Bay of Russia, through southern Sakhalin. The average incidence of infestation was apparently lower in $A$. japonica and A. vulgaris.
Because of the large scatter of data, interspecific and geographical differences were tested by variance analysis. Prior to this analysis, the incident data in Table 1 was transformed to arcsin and sampling sites were grouped into three, i.e., northern (1-9 in Fig. 1), central (10-19), and western (20-26). The analysis showed that the incident was significantly different interspecifically and geographically (F-test, $P<0.05$ ). Further analysis with a Least-Significant-Difference (LSD)-test between means (Snedecor \& Cochran, 1967) revealed three distinct mean groups for interspecific data: a high incidence group (Archaeomysis sp. and $A$. kokuboi), intermediate incidence group (A. vulgaris) and a low incidence group (A. 


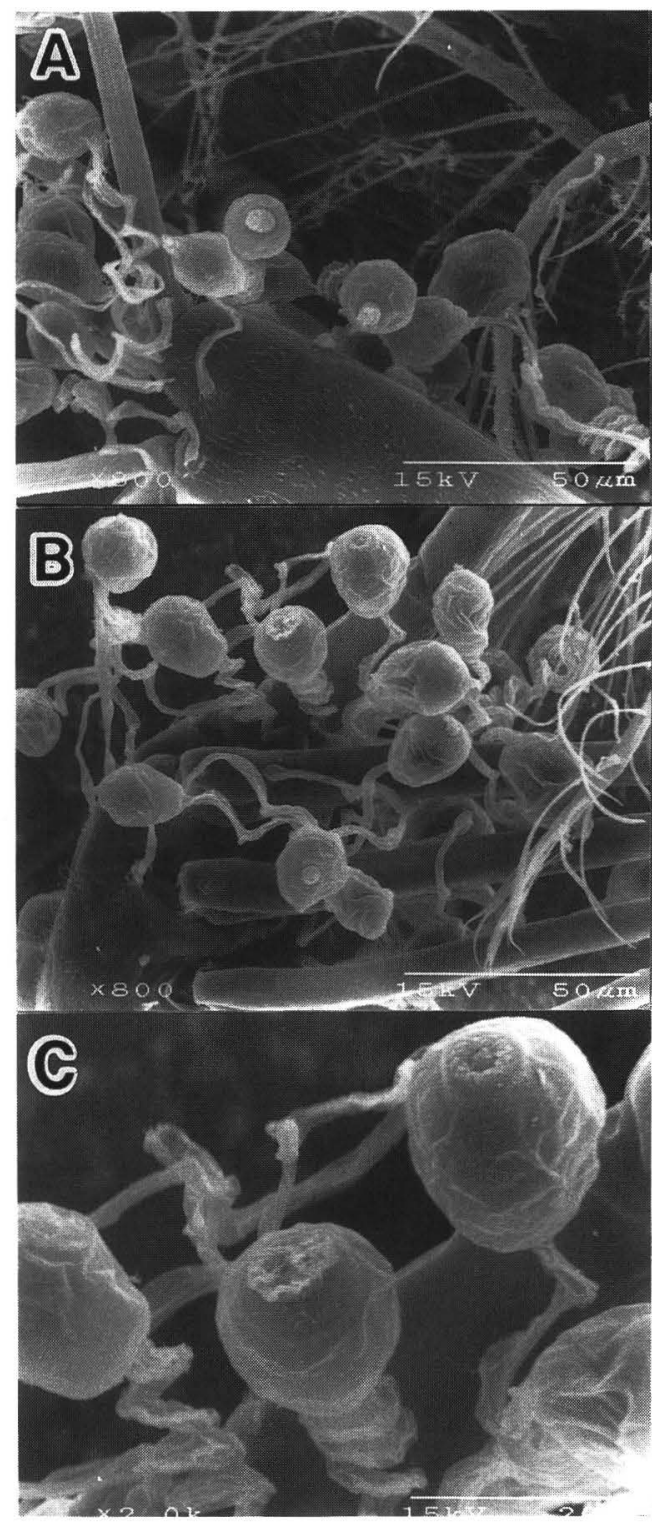

japonica), and two distinct mean groups for geographical data: a high incidence group (northern and central areas) and a low incidence group (western area).

To clarify the difference in incidence between mysids of the intertidal zones (Archaeomysis sp. + A. kokuboi $+A$. vulgaris) and those inhabiting the infralittoral bottoms (A. japonica), the mean values between the two groups

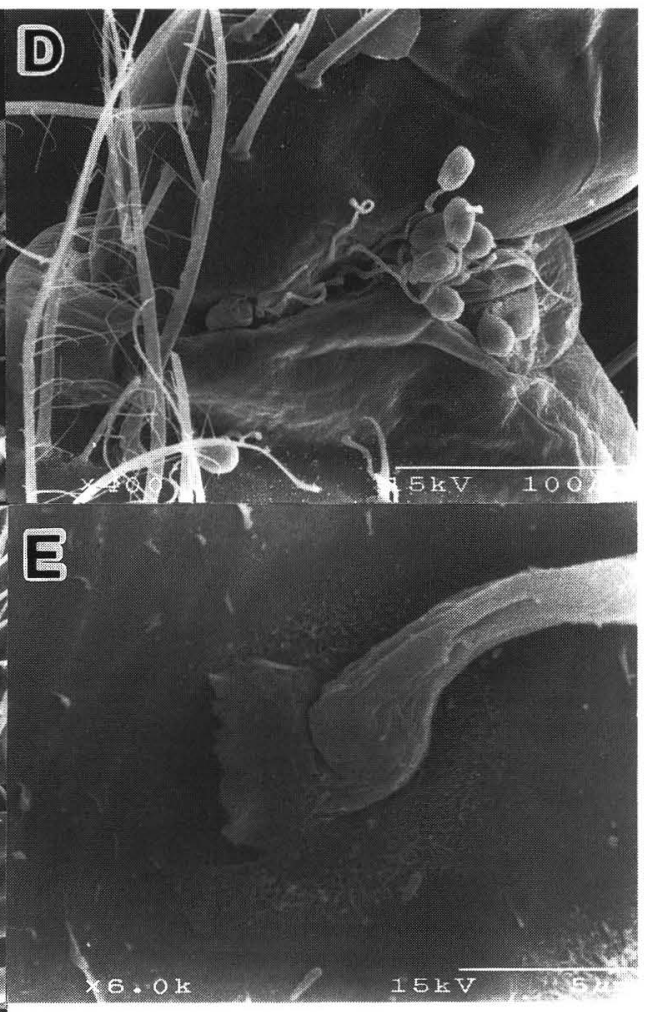

Fig. 3. Archaeomysis kokuboi infested with epibiontic peritrichs. a, first pleopod of adult female infested with many peritrichs; $b$, enlarged figure showing peritrichs attached to the distal part of pleopods and their setae; c, zooid of contractile peritrich; $d$, contractile peritrich colonies attached to the joint between two articulations of the thoracic limb; e, attachment disc of contractile peritrich showing no bacterial colonies/beds around it.

were tested according to Snedecor \& Cochran (1967). The analysis resulted in singnificant difference between the two habitat groups (t-test, $P<0.01$ ), indicating that the higher incidence is associated with mysids of the intertidal zones of sandy beaches than those from the infralittoral bottoms.

Figure 4 shows the results of one yearlong survey of seasonal changes of ciliate 


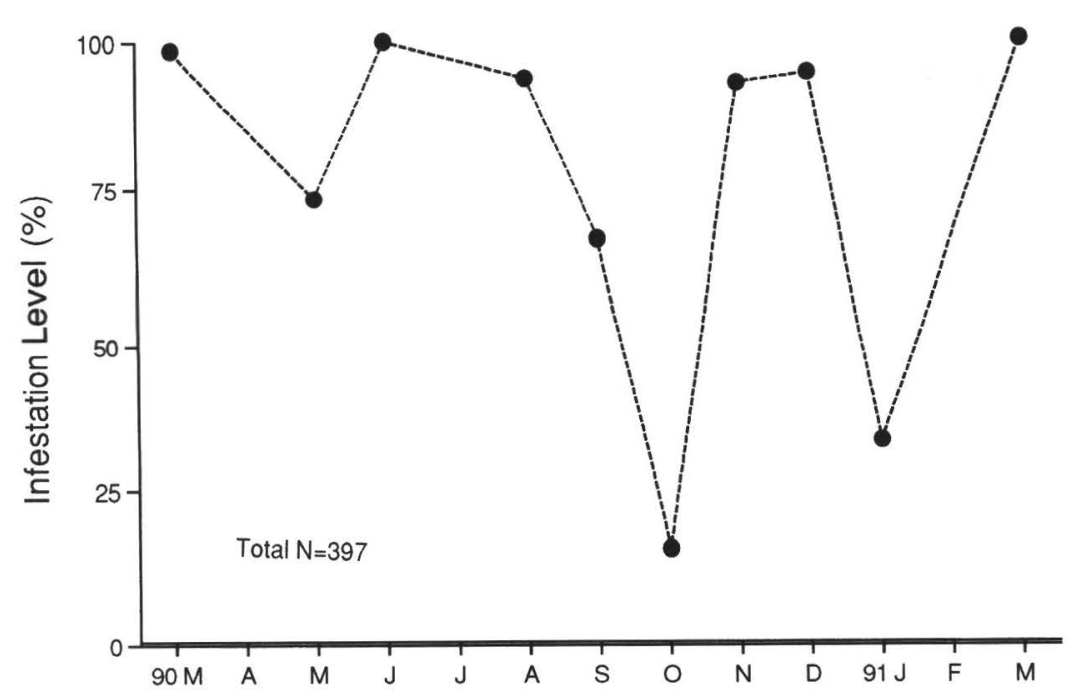

Fig. 4. Seasonal changes of Archaeomysis sp. infested by epibiontic peritrichs on the sandy beach of Tomakomai, Hokkaido, northern Japan (sampling site 7 in Fig. 1).

infestations in Archaeomysis sp. from a sandy beach of Tomakomai in Hokkaido, northern Japan, from March 1990 through March 1991. The incidence of the mysids associated with the ciliates fluctuated between 16.6 and $100 \%$. In most months, infestation level exceeded $50 \%$ (exceptions were October and January data). While run-test (Tate \& Clelland, 1957) failed to find any significant trend in these data $(P>0.05)$, it is clear that the Archaeomysis-peritrich association is established throughout the year.

\section{Discussion}

Among four Archaeomysis species examined in the present study, Archaeomysis sp. and A. kokuboi, occurring on the northern coasts of the Sea of Japan from northern Honshu to Pojet Bay, through southern Sakhalin, were infested heavily with peritrich ciliates. Compared with these two mysids, the infestation was less in A. japonica and A. vulgaris which occur on the coasts of central Honshu to southwestern Honshu or Kyushu. Scherman \& Schaner (1965), Lindley (1978) and Nicol (1984) examined the crustacean-epizoic ciliate associations, and demonstrated that infestation level varied noticeably depending on geographic locations. The present results indicate that the incidence of attached peritrichs to Archaeomysis was higher for the species inhabiting northern and central areas than those occurring in the western area, thus suggesting an affinity of peritrichs to colder environments.

In addition to water temperature, the depth distribution of host mysids may be attributed to their infestation level. Incidence in Archaeomysis japonica collected from infralittoral bottoms was consistently lower than that in those of the other three species obtained in the intertidal zone of sandy beaches even in northern Japan (Table 1), implying that the Archaeomysis-peritrich association is established most successfully in the harsh zone of the sandy beaches of boreal waters. Matsudaira et al. (1952), Jo \& Hanamura (1993), and Hanamura (unpublished) have indicated that Archaeomysis sp., A. kokuboi, and A. vulgaris are essentially the inhabitants of the swash zone of the open sandy beaches. Also, the above authors have noted a pe- 
culiar swimming and subsequent burrowing behavior of these mysids at the intertidal zones in accordance with wave actions during the day. In contrast, $A$. japonica is considered an infralittoral bottom dweller, spending a benthic life during daylight hours. At least a part of population migrates into the water column at night (Hanamura et al., 1996). The continuous burrowing and swimming of the intertidal mysids (Archaeomysis sp., A. kokuboi and A. vulgaris) over the day may provide better chance for peritrich ciliates to capture their foods, coupled with possible higher accumulation of their prey along the shore lines. To support this, we have examined some hundred specimens of Neomysis spp. (N. czerniawskii, N. mirabilis) from shallow depths around Hokkaido, including several localities at where many Archaeomysis specimens were collected also. These Neomysis spp. are basically hyperbenthic and, do not penetrate into the sand at all. The result of this examination demonstrated no individuals of Neomysis carrying the peritrichs of the same types attached to Archaeomysis. Hence, the sand-burrowing behavior, common to the Archaeomysis species, is considered to be a prime condition for these peritrich ciliates to attach the hosts, and then to survive on them.

Heneby \& Ridgeway (1979) found the epibiontic ciliates to be attached at almost any places of the body of some planktonic crustaceans (see also Fig. 1 in Herman \& Mihursky, 1964; Fig. 1 in Turner et al., 1979 , and others). In contrast, the location of the peritrichs attached to mysids found in this study was entirely limited to the underside of the body, particularly on the pleopods and the bases of the last thoracic limbs. Wave action results in strong sand movements in the harsh zone of open sandy beaches. As Archaeomysis can penetrate only the top $1 \mathrm{~cm}$ of the sand (Kamihira, 1979), the dorsal surface of the body of mysids is considered to be ex- posed to the flow of moving sand particles. Thus, attachment of peritrichs under the body of mysids may be more advantageous for protecting them against the physically harsh environment of sandy beaches.

Larger mysids were frequently observed to carry a larger number of peritrichs. The larger body size implies a longer intermoult period. This, coupled with a larger surface area on which the ciliates could settle, provides more opportunity for peritrichs to attach to larger specimens. High incidence (near $100 \%$ of the entire population) of infestation of the mysids of various size classes indicates that the ciliates are able to re-attach quickly to new cuticle after the moulting of mysids. Lindley (1978) mentioned that the percent occurrence of the apostome ciliate on the five euphausiid species in the North Atlantic has a positive and linear relationship with size. In contrast, Evans et al. (1981) reported that infestation of the suctorian Tokophyra sp. on Neomysis relicta in the Great Lakes region was size independent.

The seasonal infestation data on Archaeomysis (Fig. 4) suggests that infestation of peritrichs on the mysid occurs all the year round. At the sampling site of this seasonal study, water temperature ranged from 3.5 to $23.9^{\circ} \mathrm{C}$, suggesting that the ciliate is capable of survival in this wide temperature range. Unfortunately, salinity and other environmental properties were not monitored in this study, so that we could not analyse what kinds of environmental parameters contributed to the observed sharp decrease/ recovery patterns of the incidence of infestations. Open sandy beaches, as a rule, are one of the most dynamic environments in the marine ecosystem, reflecting high energy wave action, sand movement, and a wide range of temperature and salinity changes as well as food supply (Brown \& McLachlan, 1990). Under such circumstances, the peritrich ciliates are 
considered to be an opportunist and they can attach to the host immediately as the environmental conditions became favorable for their growth and reproduction.

It is not known explicitly about the causative effect of epizoic ciliates on their crustacean hosts. The ciliate epibiont may cause damage more or less to individual hosts; inflame the cuticle, impair gas exchange, interfere with mobile activity or act as a stressor (Overstreet, 1973; Lightner, 1975; Couch, 1978, 1983; Evans et al., 1979; Evans et al., 1981; Nagasawa, 1986). It was pointed out that the epibiontes give serious impact to natural copepod populations, resulting in a change over in specific dominance due to certain disadvantages by heavier infestations (Herman \& Mihursky, 1964; Turner et al., 1979; Nagasawa, 1986). In this light, our observations of peritrich infested Archaeomysis with the binocular microscope and the SEM indicated neither injuries of hosts, nor intensive bacterial colonies (or beds) associated with peritrich ciliates. Archaeomysis constitutes the major component in the sandy beach macrofaunal community throughout the year in northern Japan, with higher density in summer to autumn (Hanamura, unpublished). While the investigation is currently limited to Hokkaido, higher incidence of the epibiontes has been observed to be not related to the decrease of the mysid populations, and the seasonal variation of the population density of each mysid species is little affected by the infestation of peritrich ciliates, as has been noted in some crustacean populations by several previous researchers (Scherman \& Schaner, 1965; Evans et al., 1979; Evans et al., 1981; Henebry \& Ridgeway, 1979; Nicol, 1984). Notwithstanding, possible damage to individual mysids, particularly younger animals, by heavy infestation cannot be ruled out entirely.

\section{Acknowledgments}

We owe our gratitude to Dr. T. Ikeda of the Nansei National Fisheries Research Institute, Hirosima, for his kind reading and many constructive comments on the manuscript. Our thanks go to Dr. A. Warren of the Natural History Museum, London for his help to identify the epibionts. We thank Dr. M. Maeda of the National Institute of Aquaculture, Nansei-cho, Mie, for his various facilities during this study. We express our appreciation to Dr. V. Wadley of the CSIRO Division of Fisheries for kindly reading the manuscript. Finally, we acknowledge the many people who have assisted in collecting mysids over the past ten years.

\section{Literature Cited}

Brown, A. C., \& McLachlan, A., 1990. Ecology of sandy shores. 328 pp., Elsevier, Amsterdam.

Couch, J. A., 1978. Diseases, parasites, and toxic responses of commercial penaeid shrimps of the Gulf of Mexico and South Atlantic coasts of North America. Fishery Bulletin, 76: 1-44.

, 1983. Diseases caused by Protozoa. In: Provenzano, A. J. Jr. (ed.), The biology of Crustacea. Vol. 6. Pathobiology. 79-111 pp., Academic Press, New York.

Evans, M. S., Sicko-Goad, L. M., \& Omair, M., 1979. Seasonal occurrence of Tokophyra quadripartita (Suctoria) as epibionts on adult Limnocalanus macrurus (Copepoda: Calanoida) in southeastern Lake Michigan. Transactions of the American Microscopical Society, 98: 102-109.

— Sell, D. W., \& Beeton, A. M., 1981. Tokophyra quadripartita and Tokophyra sp. (Suctoria) associations with crustacean zooplankton in the Great Lakes region. Transactions of the American Microscopical Society, 100: 384-391.

Hanamura, Y., Jo, S.-G., \& Murano, M., 1996. A new species of Archaeomysis (Mysidacea, Gastrosaccinae) from coastal waters of Japan. Crustaceana, 69: 553-566.

Henebry, M. S., \& Ridgeway, B. T., 1979. Epizoic ciliated protozoa of planktonic copepods and cladocerans and their possible use as indicators of organic water pollution. Transactions of the American Micro- 
scopical Society, 98: 495-508.

Herman, S. S., \& Mihursky, J. A., 1964. Infestation of the copepod Acartia tonsa with the stalked ciliate Zoothamnium. Science, 146: 543-544.

Hoenigman, J., 1960. Faits nouveaux concernant les mysidacés (Crustacea) et leurs epibiontes dans l'Adriatique. Rapport et Proces-Verbaux des Réunions. Commision internationale pour l' Exploration scientifique de la mer Mediterranée, 15: $339-343$.

Jo, S.-G., \& Hanamura, Y., 1993. Redescription of Archaeomysis vulgaris (Nakazawa, 1910) comb. nov. (Crustacea: Mysidacea: Gastrosaccinae). The Korean Journal of Systematic Zoology, 9: 103-113.

Kamihira, Y., 1979. Ecological studies of macrofauna on a sandy beaches of Hakodate, Japan. II. On the distribution of peracarids and the factors influencing their distribution. Bulletin of the Faculty of Fisheries, Hokkaido University, 30: 133143. (In Japanese)

Lightner, D. V., 1975. Some potentially serious disease problems in the culture of penaeid shrimp in North America. Proccedings of the third U.S.-Japan Meeting on Aquaculture at Tokyo, Japan Octorber 15-16, 1974. Special Publication of Fishery Agency, Japanese Government and the Japan Sea Regional Fisheries Research Laboratry: 75-97.

Lindley, J. A., 1978. Continuous Plankton Records: the occurrence of apostome ciliates (Protozoa) on Euphausiacea in the North Atlantic Ocean and North Sea. Marine Biology, 46: 131-136.

Matsudaira, C., Kariya, T., \& Tsuda, T., 1952. The study on the biology of a mysid, Gastrosaccus vulgaris Nakazawa. Tohoku Journal of Agricultural Research, 3: 155174.

Mauchline, J., 1980. The biology of mysids and euphausiids. Advances in Marine Biology, 18: 1-681.

Nagasawa, S., 1986. The peritrich ciliate
Zoothamnium attached to the copepod Centropages abdominalis in Tokyo Bay waters. Bulletin of Marine Science, 38: 553558.

Nicol, S., 1984. Ephelota sp., a suctorian found on the euphausiids Meganyctiphanes norvegica. Canadian Journal of Zoology, 62: 744-746.

Overstreet, R. M., 1973. Parasites of some penaeid shrimps with emphasis on reared hosts. Aquaculture, 2: 105-140.

Sawyer, T. K., MacLean, S. A., \& Ziskowski, J., 1976. A report on Ephelota sp. (Ciliata, Suctorida) as an epibiont on the gills of decapod crustaceans. Transactions of the American Microscopical Society, 95: 712717.

Sherman, K., \& Schaner, E. G., 1965. Paracineta sp., an epizoic suctorian found on Gulf of Maine Copepoda. Journal of Protozoology, 12: 618-625.

Snedecor, G. W., \& Cochran, R. C., 1967. Statistical Methods. 6th ed. Iowa State University Press, Ames, Iowa. (Japanese ed. in 1972)

Takayama, H., 1981. Preparation of red tide plankton for scanning electron microscopy. Bulletin of the Hirosima Fisheries Experimental Station, 11: 101-112. (In Japanese)

Tate, M. W., \& Clelland, R. C., 1957. Nonparametric and shortcut statistics. Interstates Printer \& Publishers, Inc., Danville, Illinois.

Tattersall, W. M., \& Tattersall, O. S., 1951. The British Mysidacea. 460 pp. Ray Society, London.

Turner, J. T., Postek, M. T., \& Collard, S. B., 1979. Infestation of the estuarine copepod Acartia tonsa with the ciliate Epistylis. Transactions of the American Microscopical Society, 98: 136-138.

Address: Nansei National Fisheries Research Institute, Ohno-cho, Hiroshima 73904, Japan.

E-mails: (YH) hanamura@nnf.affrc.go.jp; (KN) nagasaki@nnf.affrc.go.jp 